\title{
House Price, Ownership Type and Firm Innovation
}

\author{
Ruo Wang \\ Department of Accounting, School of Management, Jinan University, Guangzhou, China \\ Email: peggy_ruo@126.com
}

How to cite this paper: Wang, R. (2017) House Price, Ownership Type and Firm Innovation. Open Journal of Social Sciences, 5, 339-351.

https://doi.org/10.4236/jss.2017.57021

Received: June 16, 2017

Accepted: July 21, 2017

Published: July 24, 2017

Copyright $\odot 2017$ by author and Scientific Research Publishing Inc. This work is licensed under the Creative Commons Attribution International License (CC BY 4.0).

http://creativecommons.org/licenses/by/4.0/

\section{(c) (i) Open Access}

\begin{abstract}
This paper chooses the data of high-tech enterprises in China from 2007 to 2014, and investigates the impact of house price on firm innovation. The conclusion is that the house prices are significantly negatively related to the firm innovation, and compared to the prices of the operating buildings and the office buildings, the negative effect of the increasing price of commercial buildings as a whole, residential buildings (large categories), or other commercial building in the similar category is more significant. Besides, the paper also found that the negative effect on state-owned enterprise innovation is more significant than the non-state-owned enterprise innovation. The conclusion of this paper has a certain guiding significance for exploring the negative impact of rising house prices on the enterprise innovation.
\end{abstract}

\section{Keywords}

House Price, New High-Tech Enterprise, Innovation, Ownership Type

\section{Introduction}

With the new normal of China's economy, innovation is becoming an indispensable development concept, and it is increasingly vital for enterprises to improve their creativity. Moreover, after the abolition of the welfare housing distribution system in 1998, the real estate industry rose rapidly and began to market. In 2004, house prices soared up without limit and the real estate industry continued to grow at a high speed until the outburst of the financial crisis in 2008, which slowed down the pace of house prices. Then, however, the prices returned to the normal situation [1]. Aimed at changing the condition of the industry, the real estate regulation policy is issued by our country frequently, and with the expectation for the crowed who live in the large and medium cities, the house prices recovered more quickly in early 2016, and the 
volume of the real estate increased significantly, even appeared the crazy trend.

In recent years, we have found that more and more companies tend to invest in the real estate, and apart from the high-tech enterprises, it is reasonable to reduce the input of the $\mathrm{R} \& \mathrm{D}$, when investing the real estate can bring the lucrative earnings. However, it doesn't means that the reaction has reached to the "Pareto Optimal State", especially when it comes to the sustainable development of the enterprises. And as is known to all, the real estate industry will not be prosperous all the time, once the financial crisis break out again, it must endanger the subsistence and development of the firms [2]. In short, it can effectively provide the firms with the reference frame to research the impact of the house price on the firm innovation.

We find that China's research on enterprise innovation, mostly using the industrial enterprises as the sample. According to this situation and to complete the research on the firm innovation, this paper screens out the manufacturing and information technology industry whose R\&D activities are more abundant, and chooses the A-share listed companies of the above-mentioned two industries as the sample to research on, and because of the fact that the innovation activities of the firms in the other industries are relatively few and we can't get enough and related information.

The paper has the practical social significance and academic significance. The academic significance is as follows, we know that there are many literature that study the enterprise innovation, and it is generally believed that the real estate bubble may have a positive effect on the productive investment of enterprises. And most of the empirical researches focus on the positive impact. But this paper starts from the house price which is related to people's livelihood, and also studies the inhibitory effect on the productive investment of the firms. Then it found that when the house price increases, the enterprise innovation will be inhibited, and compared to the non-state-owned enterprises, when the house prices rise, the state-owned enterprises will suppress the innovation more significantly. To sum up, this article enriches the theoretical knowledge of the enterprise innovation with a more novel angle to conduct the research, and provides the new product $\mathrm{R} \& \mathrm{D}$ investment with a certain reference. What's more, the practical significance is that it reminds the high-tech enterprises of focusing on their own primary business, if they struggle to put the fund into the real estate industry to pursue the excess profit blindly, and it will hurt the research and development of the major business product, and if the firms just maintain the current situation or the update speed is too slow, the fierce competition will expel them out of the market.

The remainder of the paper is organized as follows. Section 2 shows the literature review and develops the hypotheses. Section 3 describes the sample selection and data and provides the descriptive statistics on the test and control variables. Section 4 shows the empirical relation between the house price and the firm innovation. Section 5 concludes the paper. 


\section{Literature Review and Hypothesis Development}

\subsection{Literature Review}

Innovation is a critical driving factor for sustained economic growth. Although China's research on enterprise innovation was started later than the abroad, we struggle to do the research best, and we believe that we will reach to the new high spot. Based on China's national conditions, a lot of researches and analysis have been carried out by the economists, and the economists study on the enterprise innovation from a number of influencing factors.

\subsubsection{Literature about the House Price}

House prices are the fundamental thing of people's livelihood, and the research on house prices has focused on the daily influence on the public and the housing bubble. Such as Kuang Weida (2010), Gao Bo, Wang Wenli (2013), Yan Se and Zhu Guozhong (2013), Zhao Xiliang and Liang Wenquan (2013) are all promoting the rational consumption of residential housing, and advocating that the crowed can be more reasonable to meet the real estate speculation needs, so that it can prevent house price bubbles and the economic consequences [3] [4] [5] [6]. Kuang (2010) used the adjusted model, and studied the effect of the investor expectations and investment direction on the house prices, and found that both of them have the strong explanatory power for the house price fluctuation. Yan Se, ect. (2013) utilized a specific model, and found that when the house prices rose, the national consumption reduced significantly. Zhao Xiliang et al. (2013) used the data of the income of China's residents, and found that there was a significant negative correlation between the household saving rate and the rise of the house prices. In addition, Wu Xiaoyu, Wang Min et al. (2014) also introduced the house prices in the study of entrepreneurial literature, and the paper constructed a special model, and found that house prices have an important impact on business decision-making, and the impact is different from that whether the masses have the property. Moreover, the study of house prices and firm innovation is also a novel topic [7]. Such as Wang Wenchun et al. (2014) have made empirical research on this theme. They used the data of industrial enterprises in 35 large and medium-sized cities in China, whose annual business income over 5 million yuan from 1999 to 2007, and found that the faster the house prices rose, the weaker the firm innovation tendencies are [8]. And other research on house prices has proceeded from monetary policy, such as Tan Zhengxun and Wang Cong (2015), who studied how the monetary policy respond to the house price volatility in their paper, which is conducive to the coherent and healthy operation of macroeconomics [9].

\subsubsection{Literature about the Firm Innovation}

After the concept of firm innovation was put forward, the researchers mainly concentrated on the factors which affect the business innovation, and how they affect the firm innovation at home and abroad. Firstly, the scholar studied the influence of management traits. Yi Jingtao, Zhang Xiuping et al. (2015) and C. Lin, P. Lin, F.M. Song, C. Li (2010) have confirmed that management traits con- 
tribute to the firm innovation significantly. The former selected the data of all of the A-share listed companies in the database of the Ministry of Science and Technology, and draw the conclusion that the over-confidence of the executives has promoted the input of innovative projects and improved the efficiency of innovation. This conclusion has the practical significance for the appointment of senior executives [10]. And the latter used the data of the 1088 manufacturing companies which lied in the 18 cities of China, and found that the CEO incentive program are used to increase the innovation intensity of the enterprises. In addition, they also found that there is a significant positive correlation between the CEO's education level, professional background, political relevance (that is the CEO characteristics) and firm innovation [11]. Tan Hongtao, Yuan Xiaoxing and Yang Xiaojuan (2016) and Huang Congcong (2011) also found that the implementation of the corporate equity incentive system promote the enterprise innovation significantly [12] [13]. And Chi Guohua, Yang Jin et al. (2016) and Wei Xuhua, Liu Yongmei (2015) also found that the management traits have a positive effect on the the level of innovation input [14] [15].

Secondly, the impact of the firm size on firm innovation. Zhou Li'an et al. (2005), Wu Yanbing (2007) and other scholars all study the impact empirically, and verify the positive relationship between the two. The former uses the provincial panel data from 1985 to 1997 to carry out a series of empirical analysis, and find that the positive relationship mainly comes from the non-state-owned enterprises, rather than the state-owned enterprises [16]. The latter makes a comprehensive review about the impact of firm size on the innovation at home and abroad over the years, and once again supports the positive relationship [17].

Thirdly, the impact of market concentration on firm innovation. Lee (2005) [18], Blundell, Griffith and Van Reenen (1999) [19] and Broadberry and Crafts (2000) [20] research the impact of market concentration on enterprise innovation. Lee used the information of manufacturing industry in 1983 in Korea, and the paper found that the relationship between the market forces and the intensity of R\&D depends on the degree of the specificity of the industry R\&D, and there is a significant negative correlation between the two. Zhang Jie, Zhou Xiaoyan et al. (2011) analyze the influence of factor market on the Chinese firm innovation, that is, the more difficultly the price play its role, the stronger the inhibitory effect on the R \& D will be [21].

There are many other researches on the influencing factors of the firm innovation, such as Pan Yue, Pan Jianping (2015), they use the A-listed companies of the high-tech industry, which listed in Shanghai Stock Exchange and Shenzhen Stock Exchange, as the samples, and selected the corporate litigation risk which is not certain as the independent variable, and study the impact on the innovation activities, and found that the litigation with different category have different effects on the firm innovation [22]. What's more, Su Yiyi and Zhou Changhui (2008) found that it has a positive influence on the enterprise innovation for the sample firms, which has the intricate relationships (competition and coopera- 
tion) with the various types of enterprises in their regions [23].

\subsubsection{Literature about the Ownership Type}

The property of ownership has different influence on many activities of enterprises. And many literature have used the ownership type to divide the data into groups, and then investigated the relationships between the various projects of the companies. Hong Daolin, Xiong Dehua, Liu Li (2007) study the relationship between corporate diversification and the capital structure with the China's listed firms' data from 1999 to 2003, and the result shows that ownership type makes a marked impact on this relation: diversification raises the leverage of state-owned firms significantly, while it's not the case for the non-state-owned firms [24]. Wu Dongmei, Zhuang Xintian (2010) select the A-listed companies which transferred their equity from 2001 to 2006, and research the private benefits for controlling shareholders, and the result can provide the suggestions to China's share-holder structure reform [25]. And Li Wengui, Yu Minggui (2012) use the data of listed firms in China from 1998-2011, and find that there is a significantly negative relationship between nature of ownership and corporate risktaking, and the effect mainly exists in the medium and small companies [26]. Xu Haoping, Lv Changjiang (2007), Fang Junxiong (2008), and Zhou Linjie, Qiu Xun (2013) all use the property of ownership as the grouping standard, and study the impact of the government involvement on the enterprise activities [27] [28] [29].

\subsection{Hypothesis Development}

Innovation is not only an important means for enterprises to grow up, enhance core competitiveness and obtain excess profits, but also an important source of its sustainable growth for an enterprise, a region and even a country. And Schumpeter, who put forward the theory about enterprise innovation for the first time in 1942, found that the industrial research and development laboratories, and the institutionalization of innovation can promote the firm innovation, and only the large enterprises can bear the huge $\mathrm{R} \& \mathrm{D}$ costs, and play a key role in the firm innovation. Then, economists have not stopped studying the enterprise innovation, they found that there are many factors which affects the firm innovation, including the size of enterprises (generally using the sales revenue, the total number of employees or the total assets to measure), market forces (generally using four manufacturers or the Herfindahl index to measure), the market structure, and the incentive mechanism of the managers, and the external system environment also has a significant impact on the firm innovation, and the economists also found that institutional investors can promote the enterprise innovation greatly.

With the housing system reforming deeply, the State Council put forward a comprehensive cessation of the housing welfare distribution system in July 1998, which marks that China's follow the 40-year housing system ended, and results in the consumption of commercial housing and investment needs, and which active the real estate market greatly (Kuang Weida, 2010). Moreover, the real es- 
tate industry is a high capital intensive industry, it commands the large-scale investment, long cycle. Therefore, if there is no enough finance and strong financial support, entering the real estate industry is much too difficult. And enterprises which pursue the high returns of the real estate industry, to a certain extent, must reduce the investment in corporate R\&D funds. Based on this, the first hypothesis of this paper is put forward:

H1: House prices and high-tech industry innovation has a negative correlation.

As for the state-owned enterprises, its close relationship with the local governments and the state-owned banks makes it relatively easy to enter the real estate industry. In addition, in 2016, the State Council promulgated the "Guidance on deepening the reform of state-owned enterprises," pointed out that we should rely on reforming to keep slim and fit, to improve the economic efficiency, and to increase revenue and reduce costs. Therefore, when the house prices rise, in order to obtain the appropriate return on investment, the firms will choose to finance funds to the real estate industry, then it will have a negative impact on the R\&D expenditure of the state-owned enterprises. For the non-state-owned high-tech firms, which have a lot of financing constraints, and in order to compete with the other companies in their industries to maintain the core competitiveness, and pursue their own sustainable development, they may focused more on the main business, and will not blindly chase on the high profits, so the impact of rising house prices on the negative impact of firm innovation is not significant. Then we propose a second hypothesis:

$\mathrm{H} 2$ : Compared with the non-state-owned enterprises, the house price of the state-owned enterprises are more significant in the suppression of innovation.

\section{Research Design}

\subsection{Research Samples}

This paper does not choose all the listed companies as a sample, for it takes into account that only the high-tech industry innovation activities have the greater research value. Cui \& Mak (2002) use the R\&D intensity (annual R \& D expenditure/annual sales) as the measure to conduct the research, and found that the drugs and biotechnology products, computer and office equipment, communications equipment, electronics, measurement and lab analysis instruments, medical apparatus, programming and software and so on, belong to the hightech industries [30]. And compared to the China Securities Regulatory Commission which was issued in 2011, "listed companies' industry classification guidelines", and the paper choose the manufacturing and information technology industry companies as the research sample, and use the R\&D investment intensity to measure the firm innovation, and then study the relationship between the house price and the firm innovation of the 35 large and medium cities in China.

The house price data comes from the "China Real Estate Statistical Yearbook" from 2007 through 2014, which reports "The real estate development enterprises sales price of the 35 major cities which makes a distinction according to the 
purpose". And the project includes the house price of the 35 large and medium-sized city (sales price of commercial housing, sales price of residential housing, sales price of office, sales price of operating buildings and other buildings). Based on the basic information of the high-tech enterprises, the paper matches the firm registration place and 35 large and medium cities one by one. And the remaining data is collected from the CSMAR database and the Juchao information website.

\subsection{Model Settings and Variable Descriptions}

In this paper, we use the fixed effect model to analyze the impact of house price on enterprise innovation, which by referring to the method of Li Wengui et al. (2015) and Wang Wenchun et al. (2014). And the regression model is as follows:

$$
\text { Inno }=\alpha+\beta_{1} \text { Price }_{i t}+\beta_{2} X_{i t}+\varepsilon_{i t}\left(X_{i t} \text { means the control variables }\right)
$$

Consistent with the method of Li Wengui et al. (2015), the paper chooses the $R \& D$ investment intensity to measure the firm innovation (annual R\&D expenditure/annual total asset). Moreover, In order to explore the effect of the different types of the commercial housing price on the firm innovation, this paper also divides the sales price of commercial housing into residential price, operating buildings price, office buildings and other buildings price according to the China Real Estate Statistical Yearbook. And we bring the proxy indicators of the different house price into the regression model respectively to verify the hypothesis 1, Likewise, we divide all the data into two groups according to the ownership type, and then, we bring the proxy indicators, including the commercial building price (Commercial), residential building price (Residential), office building price (Office), operating building price (Operating) and other building price (Others), into the model to conduct the regression analysis, so that it can verify the $\mathrm{H} 2$.

The paper draws on the practice of Zhou Li'an et al. (2015) and Li Wengui (2015), and introduces the following variables as control variables in the model, and also controls the annual effect and the industry effect in the regression model. The definition of each variable is shown in the Table 1.

\subsection{Descriptive Statistics}

Table 2 reports the descriptive statistics of the main variables. And the paper winsorize the continuous variables at the level $1 \%-99 \%$ to eliminate the influence of the outliers. The average for the dependent variable (Inno) indicates that, to the average extent, the ratio of the $\mathrm{R} \& \mathrm{D}$ expenditure to the total assets is 0.005 percent in the sample. And we also know from the results that the mean of State is 0.410 , which means that the largest shareholders of the 41 percent of the sample firms have the state-owned background.

\section{Results and Analysis}

\subsection{House Price and Firm Innovation}

Table 3 reports the regression results of the model, and the standard error for all 
tests has been Cluster adjusted, and the paper analyzes the impact of the different type of the commercial housing prices on the firm innovation. Column (1) reports the relation between the commercial prices and the innovation, we find that the regression coefficient of this price is -0.00404 , and significant at the level of 5 percent, which indicate that when the price of commercial housing rose $1 \%$, the intensity of investment of the enterprise innovation will reduce

Table 1. Variable definition.

\begin{tabular}{|c|c|c|}
\hline & Variable & Definition \\
\hline \multirow[t]{3}{*}{ Dependent variable } & Inno & Annual R \& D expenditure/annual total asset \\
\hline & Commercial & Ln (sales price of commercial housing) \\
\hline & Residence & Ln (sales price of residential) \\
\hline \multirow[t]{7}{*}{ Independent variable } & Office & Ln (sales price of office buildings) \\
\hline & Operating & Ln (sales price of operating buildings) \\
\hline & Others & Ln (sales price of other buildings) \\
\hline & Size & Ln (total assets) \\
\hline & Lev & Debt-to-assets ratio \\
\hline & Subsidy & Ln (government subsidy) \\
\hline & Growth & Operating income growth rate \\
\hline \multirow[t]{5}{*}{ Control variable } & ROA & Return on total assets \\
\hline & Age & Ln (age of establishment) \\
\hline & State & If it's state-owned enterprise, equals to 1 \\
\hline & Year & Year dummy variable \\
\hline & Ind & Industry dummy variable \\
\hline
\end{tabular}

Table 2. Descriptive statistics for study variables.

\begin{tabular}{ccccccc}
\hline Variables & Obs. & Mean & S.D. & Min. & Median & Max. \\
\hline Inno & 5675 & 0.005 & 0.013 & 0.000 & 0.000 & 0.162 \\
Commercial & 5675 & 9.160 & 0.575 & 7.932 & 9.166 & 10.115 \\
Residence & 5675 & 9.122 & 0.586 & 7.871 & 9.165 & 10.087 \\
Office & 5675 & 9.516 & 0.589 & 8.177 & 9.563 & 10.640 \\
Operating & 5675 & 9.555 & 0.475 & 8.535 & 9.601 & 10.454 \\
Others & 5670 & 8.701 & 0.583 & 7.434 & 8.648 & 10.431 \\
ROA & 5673 & 0.049 & 0.070 & -0.235 & 0.046 & 0.253 \\
Size & 5675 & 21.502 & 1.243 & 18.640 & 21.335 & 26.069 \\
Lev & 5673 & 0.426 & 0.250 & 0.041 & 0.415 & 1.534 \\
Subsidy & 5325 & 2.772 & 0.109 & 2.282 & 2.780 & 3.016 \\
Age & 5675 & 2.542 & 0.446 & 0.000 & 2.639 & 3.555 \\
Growth & 5118 & 0.199 & 0.522 & -0.698 & 0.129 & 4.501 \\
state & 5675 & 0.410 & 0.492 & 0.000 & 0.000 & 1.000 \\
\hline
\end{tabular}


Table 3. House price and firm innovation.

\begin{tabular}{|c|c|c|c|c|c|}
\hline & (1) & (2) & (3) & (4) & (5) \\
\hline COEFFICIENT & $\begin{array}{c}\text { Price } \\
=\text { Commercial }\end{array}$ & $\begin{aligned} & \text { Price } \\
= & \text { Residence }\end{aligned}$ & $\begin{aligned} & \text { Price } \\
= & \text { Others }\end{aligned}$ & $\begin{aligned} & \text { Price } \\
= & \text { Operating }\end{aligned}$ & $\begin{aligned} & \text { Price } \\
= & \text { Office }\end{aligned}$ \\
\hline Variable & & & Inno & & \\
\hline Price & $\begin{array}{c}-0.00404^{* *} \\
(-2.30)\end{array}$ & $\begin{array}{c}-0.00400^{\star *} \\
(-2.31)\end{array}$ & $\begin{array}{c}-0.00119^{* *} \\
(-2.49)\end{array}$ & $\begin{array}{c}-0.00129 \\
(-1.64)\end{array}$ & $\begin{array}{c}0.000893 \\
(1.12)\end{array}$ \\
\hline Size & $\begin{array}{c}-0.000134 \\
(-0.27)\end{array}$ & $\begin{array}{c}-0.000128 \\
(-0.26)\end{array}$ & $\begin{array}{c}-0.000151 \\
(-0.30)\end{array}$ & $\begin{array}{c}-0.000147 \\
(-0.29)\end{array}$ & $\begin{array}{c}-0.000148 \\
(-0.29)\end{array}$ \\
\hline Age & $\begin{array}{c}0.00702^{\star *} \\
(2.24)\end{array}$ & $\begin{array}{l}0.00704^{\star *} \\
(2.24)\end{array}$ & $\begin{array}{l}0.00748^{\star *} \\
(2.38)\end{array}$ & $\begin{array}{c}0.00677^{\star *} \\
(2.15)\end{array}$ & $\begin{array}{c}0.00702^{\star *} \\
(2.24)\end{array}$ \\
\hline Subsidy & $\begin{array}{c}0.00539^{\star * *} \\
(3.26)\end{array}$ & $\begin{array}{c}0.00536^{* * *} \\
(3.24)\end{array}$ & $\begin{array}{c}0.00552^{\star * *} \\
(3.34)\end{array}$ & $\begin{array}{c}0.00536^{* * *} \\
(3.25)\end{array}$ & $\begin{array}{c}0.00545^{* * *} \\
(3.28)\end{array}$ \\
\hline Growth & $\begin{array}{c}-0.000295 \\
(-1.35)\end{array}$ & $\begin{array}{c}-0.000287 \\
(-1.31)\end{array}$ & $\begin{array}{c}-0.000278 \\
(-1.27)\end{array}$ & $\begin{array}{c}-0.000293 \\
(-1.34)\end{array}$ & $\begin{array}{c}-0.000287 \\
(-1.31)\end{array}$ \\
\hline Lev & $\begin{array}{c}-0.00176 \\
(-1.16)\end{array}$ & $\begin{array}{c}-0.00173 \\
(-1.14)\end{array}$ & $\begin{array}{c}-0.00177 \\
(-1.17)\end{array}$ & $\begin{array}{c}-0.00178 \\
(-1.17)\end{array}$ & $\begin{array}{c}-0.00175 \\
(-1.14)\end{array}$ \\
\hline ROA & $\begin{array}{c}0.000574 \\
(0.17)\end{array}$ & $\begin{array}{c}0.000565 \\
(0.17)\end{array}$ & $\begin{array}{c}0.000467 \\
(0.14)\end{array}$ & $\begin{array}{c}0.000572 \\
(0.17)\end{array}$ & $\begin{array}{c}0.000511 \\
(0.15)\end{array}$ \\
\hline Constant & $\begin{array}{l}0.0106 \\
(0.58)\end{array}$ & $\begin{array}{c}0.00996 \\
(0.56)\end{array}$ & $\begin{array}{l}-0.0157 \\
(-1.31)\end{array}$ & $\begin{array}{l}-0.0120 \\
(-0.85)\end{array}$ & $\begin{array}{c}-0.0326^{\star *} \\
(-2.39)\end{array}$ \\
\hline Year & & & Controlled & & \\
\hline Industry & & & Controlled & & \\
\hline Observations & 4819 & 4819 & 4816 & 4819 & 4819 \\
\hline R-squared & 0.06 & 0.06 & 0.06 & 0.06 & 0.06 \\
\hline
\end{tabular}

$* * *, * *, *$ denote significance at the 1,5 , and 10 percent levels, respectively.

$0.00404 \%$. What is more, the column (2), (3), (4), (5) are the results of the regression. Except the (4) and (5) columns (Price = Operating, Office), the rest of the classification of commercial housing sales price and business innovation has a significant negative correlation.

\subsection{House Price, Ownership Type and Firm Innovation}

I also performed a regression on the subsample of the high-tech firms (The result is in the last page, that is the Table 4). And we can make a contrast of the Panel (1) and Panel (2), then it finds that the regression coefficient of the variable Commercial and Others is negative significantly at the $10 \%$ significance level, when the coefficient of the variable Residence and Operating is negative significantly at the 5\% significance level in the Panel (2). What's more, the coefficients of the independent variables are not significant at all in the Panel (1). Therefore, the results verify the hypothesis $\mathrm{H} 2$.

\section{Conclusions}

This paper chooses the data of high-tech enterprises in China from 2007 to 2014, 
Table 4. House price, ownership type and firm innovation.

\begin{tabular}{|c|c|c|c|c|c|c|c|c|c|c|}
\hline & \multicolumn{5}{|c|}{ (1) Non-state-owned enterprises } & \multicolumn{5}{|c|}{ (2) State-owned enterprises } \\
\hline VARIABLE & & & Inno & & & & & Inno & & \\
\hline Commercial & $\begin{array}{c}-0.00242 \\
(-0.90)\end{array}$ & & & & & $\begin{array}{c}-0.00477^{\star} \\
(-1.85)\end{array}$ & & & & \\
\hline Residence & & $\begin{array}{c}-0.00159 \\
(-0.63)\end{array}$ & & & & & $\begin{array}{c}-0.00560^{* *} \\
(-2.08)\end{array}$ & & & \\
\hline Others & & & $\begin{array}{c}-0.00122 \\
(-1.61)\end{array}$ & & & & & $\begin{array}{c}-0.00115^{*} \\
(-1.88)\end{array}$ & & \\
\hline Operating & & & & $\begin{array}{c}0.000233 \\
(0.21)\end{array}$ & & & & & $\begin{array}{c}-0.00232^{\star *} \\
(-2.01)\end{array}$ & \\
\hline Office & & & & & $\begin{array}{c}0.00181 \\
(1.39)\end{array}$ & & & & & $\begin{array}{c}-8.72 \mathrm{e}-05 \\
(-0.08)\end{array}$ \\
\hline Size & $\begin{array}{c}-0.000386 \\
(-0.57)\end{array}$ & $\begin{array}{c}-0.000389 \\
(-0.58)\end{array}$ & $\begin{array}{c}-0.000403 \\
(-0.60)\end{array}$ & $\begin{array}{c}-0.000396 \\
(-0.59)\end{array}$ & $\begin{array}{c}-0.000454 \\
(-0.67)\end{array}$ & $\begin{array}{c}0.000349 \\
(0.44)\end{array}$ & $\begin{array}{c}0.000363 \\
(0.46)\end{array}$ & $\begin{array}{c}0.000330 \\
(0.42)\end{array}$ & $\begin{array}{c}0.000315 \\
(0.40)\end{array}$ & $\begin{array}{c}0.000348 \\
(0.44)\end{array}$ \\
\hline Age & $\begin{array}{c}0.00754^{*} \\
(1.86)\end{array}$ & $\begin{array}{c}0.00750^{*} \\
(1.85)\end{array}$ & $\begin{array}{c}0.00796^{* *} \\
(1.97)\end{array}$ & $\begin{array}{c}0.00746^{*} \\
(1.86)\end{array}$ & $\begin{array}{c}0.00736^{*} \\
(1.82)\end{array}$ & $\begin{array}{c}0.00797 \\
(1.22)\end{array}$ & $\begin{array}{c}0.00815 \\
(1.25)\end{array}$ & $\begin{array}{c}0.00860 \\
(1.32)\end{array}$ & $\begin{array}{c}0.00747 \\
(1.15)\end{array}$ & $\begin{array}{c}0.00825 \\
(1.26)\end{array}$ \\
\hline Subsidy & $\begin{array}{c}0.00555^{\star \star} \\
(2.34)\end{array}$ & $\begin{array}{c}0.00553^{\star *} \\
(2.33)\end{array}$ & $\begin{array}{c}0.00570^{* *} \\
(2.41)\end{array}$ & $\begin{array}{c}0.00555^{\star *} \\
(2.33)\end{array}$ & $\begin{array}{c}0.00546^{* *} \\
(2.28)\end{array}$ & $\begin{array}{c}0.00554^{\star *} \\
(2.23)\end{array}$ & $\begin{array}{c}0.00549^{\star *} \\
(2.21)\end{array}$ & $\begin{array}{c}0.00577^{\star *} \\
(2.32)\end{array}$ & $\begin{array}{c}0.00541^{\star \star} \\
(2.17)\end{array}$ & $\begin{array}{c}0.00571^{\star *} \\
(2.31)\end{array}$ \\
\hline Growth & $\begin{array}{c}-0.000337 \\
(-0.86)\end{array}$ & $\begin{array}{c}-0.000331 \\
(-0.84)\end{array}$ & $\begin{array}{c}-0.000323 \\
(-0.82)\end{array}$ & $\begin{array}{c}-0.000325 \\
(-0.82)\end{array}$ & $\begin{array}{c}-0.000324 \\
(-0.82)\end{array}$ & $\begin{array}{c}-0.000239 \\
(-0.96)\end{array}$ & $\begin{array}{c}-0.000231 \\
(-0.93)\end{array}$ & $\begin{array}{c}-0.000218 \\
(-0.88)\end{array}$ & $\begin{array}{c}-0.000245 \\
(-0.98)\end{array}$ & $\begin{array}{c}-0.000232 \\
(-0.93)\end{array}$ \\
\hline Lev & $\begin{array}{c}-0.00213 \\
(-0.98)\end{array}$ & $\begin{array}{c}-0.00211 \\
(-0.97)\end{array}$ & $\begin{array}{c}-0.00209 \\
(-0.96)\end{array}$ & $\begin{array}{c}-0.00214 \\
(-0.97)\end{array}$ & $\begin{array}{c}-0.00206 \\
(-0.93)\end{array}$ & $\begin{array}{c}-0.00314 \\
(-1.42)\end{array}$ & $\begin{array}{c}-0.00314 \\
(-1.41)\end{array}$ & $\begin{array}{c}-0.00317 \\
(-1.42)\end{array}$ & $\begin{array}{c}-0.00315 \\
(-1.42)\end{array}$ & $\begin{array}{c}-0.00318 \\
(-1.42)\end{array}$ \\
\hline ROA & $\begin{array}{c}0.00100 \\
(0.20)\end{array}$ & $\begin{array}{c}0.000996 \\
(0.20)\end{array}$ & $\begin{array}{c}0.00107 \\
(0.21)\end{array}$ & $\begin{array}{c}0.000988 \\
(0.20)\end{array}$ & $\begin{array}{c}0.000999 \\
(0.20)\end{array}$ & $\begin{array}{c}0.000644 \\
(0.15)\end{array}$ & $\begin{array}{c}0.000616 \\
(0.14)\end{array}$ & $\begin{array}{c}0.000337 \\
(0.08)\end{array}$ & $\begin{array}{c}0.00105 \\
(0.25)\end{array}$ & $\begin{array}{c}0.000491 \\
(0.11)\end{array}$ \\
\hline Constant & $\begin{array}{c}0.00238 \\
(0.09)\end{array}$ & $\begin{array}{c}-0.00480 \\
(-0.19)\end{array}$ & $\begin{array}{c}-0.00963 \\
(-0.62)\end{array}$ & $\begin{array}{l}-0.0207 \\
(-1.16)\end{array}$ & $\begin{array}{c}-0.0335^{\star} \\
(-1.90)\end{array}$ & $\begin{array}{c}0.00230 \\
(0.07)\end{array}$ & $\begin{array}{c}0.00855 \\
(0.29)\end{array}$ & $\begin{array}{l}-0.0311 \\
(-1.31)\end{array}$ & $\begin{array}{l}-0.0157 \\
(-0.62)\end{array}$ & $\begin{array}{l}-0.0392 \\
(-1.44)\end{array}$ \\
\hline Observations & 2689 & 2689 & 2688 & 2689 & 2689 & 2130 & 2130 & 2128 & 2130 & 2130 \\
\hline R-squared & 0.04 & 0.04 & 0.04 & 0.04 & 0.04 & 0.10 & 0.10 & 0.10 & 0.10 & 0.10 \\
\hline
\end{tabular}

$* * *, * *,{ }^{*}$ denote significance at the 1,5 , and 10 percent levels, respectively.

and investigates the impact of house price on firm innovation, and not only enriches the theoretical knowledge, but also provides the sustained development and $R \& D$ activities with the reference. In addition, it is more targeted for this paper to choose the high-tech enterprises as the sample. Moreover, it points out that when the house price rises, the firm innovation will be restrained, which is different from the focus that the previous studies concentrate on, for the previous literature generally argues that the real estate bubble may have a positive impact on the productive investment of the enterprises. And most of the empirical research is studying the positive effect. 
The result shows that house prices are negatively related to firm innovation significantly, and compared to operating buildings and office buildings, when the commercial housing as a whole, residential (large categories) and other types of commercial housing sales price increases, and the enterprise innovation will be inhibited more significantly. This article also found that the negative effect on state-owned enterprise innovation is more significant than the non-state-owned enterprise innovation. And the reasons are as follows. From the perspective of speculation, when the house price is too high or the price grows too fast, it can make the business investment more short-sighted. However, the innovation is a long-term investment for the enterprises, which can negatively affect the innovation of enterprises. What's more, the high house price increases the cost of living, and the employees are forced to live in the second and third-tier cities, which results in the loss of their talents and also have a negative impact on the firm innovation. The conclusions of this paper help to prevent the negative effect of the house price on the firm innovation. That is, enterprises should base on and focus on the primary business and improve their core competitiveness, and then enterprises can gain more benefits in the sustained development. In addition, enterprises can consider the incentives to allocate housing or sell houses cheaply according to the performance or the R \& D achievements of the R \& D personnel. What's more, the state can introduce relevant policies to raise the barriers to real estate entry, and restrict the enterprises to invest in real estate industry, so as to reduce the negative effect of housing price on enterprise innovation.

However, there are some deficiencies in this paper. After getting the excess profit by investing in the real estate, whether the enterprises will facilitate their main operation or not, and then stimulate the $\mathrm{R} \& \mathrm{D}$ of the new product. Due to the limitations of the data, we cannot provide more sufficient evidence for this problem, which needs the further study.

\section{References}

[1] Miao, J.J. and Wang, P.F. (2012) Sectoral Bubbles and Endogenous Growth. Working Paper. http://ssrn.com/abstract=2036597

[2] Guadalupe, M., Kuzmina, O. and Thomas, C. (2012) Innovation and Foreign Ownership. The American Economic Review, 102, 3594-3627. https://doi.org/10.1257/aer.102.7.3594

[3] Weida, K. (2010) Expectation, Speculation and Urban Housing Price Volatility in China. Economic Research Journal, 2, 67-78.

[4] Gao, B., Wang, W.L. and Li, X. (2013) Expectation, Income Inequality and the Puzzle of City's Housing Price to Rent Scissors in China. Economic Research Journal, 6, 100-112.

[5] Yan, S. and Zhu, G.Z. (2013) The Mortgage Effect or The Wealth Effect?-A Theoretical Analysis of the Impact of Rising House Prices on National Consumption. Management World, 3, 34-47.

[6] Zhao, X.L., Liang, W.Q. and Li, S. (2013) Can Growing Housing Prices Explain High Household Saving Rates in Urban China?-An Empirical Analysis Using CHIPs Data. China Economic Quarterly, 13, 81-102. 
[7] Wu, X.Y., Wang, M. and Li, L.X. (2014) Did High Housing Price Discourage Entrepreneurship in China? Economic Research Journal, 9, 121-134.

[8] Wang, W.C. and Rong, Z. (2014) A Research about the Impact of Rising House Prices on Innovation in Industrial Enterprises. China Economic Quarterly, 13, 465490.

[9] Tan, Z.X. and Wang, C. (2015) The Fluctuation of House Prices, Stance and Response of Monetary Policy. Economic Research Journal, 1, 67-83.

[10] Yi, J.T., Zhang, X.P. and Wang, H.C. (2015) Firm Heterogeneity, Top Executives' Overconfidence, and Corporate Innovation Performance. NanKai Business Review, 18, 101-112.

[11] Lin, C., Lin, P. and Song, F.M. (2010) Property Rights Protection and Corporate R\&D: Evidence from China. Journal of Development Economics, 93, 49-62. https://doi.org/10.1016/j.jdeveco.2009.04.006

[12] Tan, H., Yuan X. and Yang, X. (2016) Does Equity Incentive Enhance Firm Innovation-Empirical Evidence from Chinese Listed Companies. R\&D Concrete Contractors, 28, 1-11.

[13] Huang, C. (2011) Ownership Type, Equity Incentive and Enterprise Rapid Technological Innovation-Based on the Experience Analysis of Companies Listed on SMEs Board in China. Public Finance Research, 9, 71-74.

[14] Chi, G., Yang, J. and Zhang, B. (2016) Has EVA Assessment Improved Enterprise Independent Innovation Capacity? -Research on the Perspective of Managers' Risk Characteristics and the Nature of the Industry. Audit \& Economy Research, 1, 55 64.

[15] Wei, X., Liu, Y. and Yue, L. (2015) The Impact of Top Management Team Power Disparity on Firm Innovation Intensity: Moderated Mediating Effect. NanKai Business Review, 18, 24-33.

[16] Zhou, L. and Luo, K. (2005) Firm Size and Innovation: Evidence from China's Province-Level Data. China Economic Quarterly, 4, 623-638.

[17] Wu, Y. (2007) Firm Size, Market Concentration and Innovation: A Survey. Economic Research Journal, 5, 125-138.

[18] Lee, C.-Y. (2005) A New Perspective on Industry R\&D and Market Structure. Journal of Industrial Economics, 53, 101-122. https://doi.org/10.1111/j.0022-1821.2005.00247.x

[19] Blundell, R., Griffith, R. and Van Reenen, J. (1999) Market Share, Market Value and Innovation in a Panel of British Manufacturing Firms. Review of Economic Studies, 66, 529-554. https://doi.org/10.1111/1467-937X.00097

[20] Broadberry, S. and Crafts, N. (2000) Competition and Innovation in 1950's Britain. Working Paper No. 57, London School of Economics, London.

[21] Zhang, J., Zhou, X. and Li, Y. (2011) Does Factor Market Distortion Barrage Chinese Firms' R\&D. Economic Research Journal, 8, 78-91.

[22] Pan, Y., Pan, J. and Dai, Y. (2015) Litigation Risk, Judicial Local Protectionism and Innovation. Economic Research Journal, 3, 131-145.

[23] Su, Y. and Zhou, C. (2008) Enterprise Innovation Cluster Drivers. Management World, 3, 94-104.

[24] Hong, D., Xiong, D. and Liu, L. (2007) Ownership, Corporate Diversification and the Endogeneity of Capital Structure of China's Listed Firms. China Economic Quarterly, 6, 1165-1184.

[25] Wu, D. and Zhuang, X. (2010) The Nature of Ownership, Corporate Governance 
and Private Benefits of Control: Evidence from China's Listed Companies. Management Review, 22, 53-60.

[26] Li, W. and Yu, M. (2015) The Shareholding Structure of Privatization Enterprises and Firm Innovation. Management World, 4, 112-125.

[27] Xu, H. and Lv, C. (2007) Role of Government, Ownership Property and Cost of Equity. Accounting Research, 6, 61-67.

[28] Fang, J. (2008) The Government Intervention, the Nature of Ownership and Enterprises' Mergers \& Acquisitions. Management World, 9, 118-148.

[29] Zhou, L. and Qiu, X. (2013) Political Connection, Corporate Ownership and CEO Turnover. Journal of Financial Research, 10, 194-206.

[30] Cui, H. and Mak, Y.T. (2002) The Relationship between Managerial Ownership and Firm Performance. Journal of Corporate Finance, 8, 313-336.

https://doi.org/10.1016/S0929-1199(01)00047-5

\section{Scientific Research Publishing}

Submit or recommend next manuscript to SCIRP and we will provide best service for you:

Accepting pre-submission inquiries through Email, Facebook, LinkedIn, Twitter, etc. A wide selection of journals (inclusive of 9 subjects, more than 200 journals)

Providing 24-hour high-quality service

User-friendly online submission system

Fair and swift peer-review system

Efficient typesetting and proofreading procedure

Display of the result of downloads and visits, as well as the number of cited articles

Maximum dissemination of your research work

Submit your manuscript at: http://papersubmission.scirp.org/

Or contact jss@scirp.org 